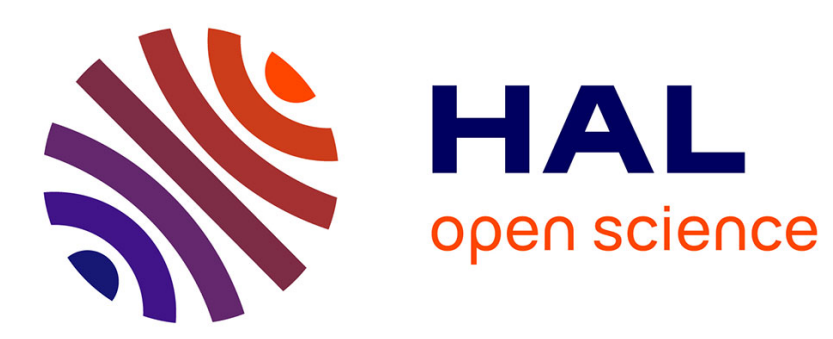

\title{
Triggering of Volcanic Pulses in the Campanian Area, South Italy, by Periodic Deep Magma Influx
}

\author{
Martine Paterne, Francois Guichard, Mart [ Ne
}

\section{To cite this version:}

Martine Paterne, Francois Guichard, Mart [ Ne. Triggering of Volcanic Pulses in the Campanian Area, South Italy, by Periodic Deep Magma Influx. Journal of Geophysical Research : Solid Earth, 1993, 98 (B2), pp.1861-1873. 10.1029/92JB02662 . hal-03543423

\section{HAL Id: hal-03543423 https://hal.science/hal-03543423}

Submitted on 26 Jan 2022

HAL is a multi-disciplinary open access archive for the deposit and dissemination of scientific research documents, whether they are published or not. The documents may come from teaching and research institutions in France or abroad, or from public or private research centers.
L'archive ouverte pluridisciplinaire HAL, est destinée au dépôt et à la diffusion de documents scientifiques de niveau recherche, publiés ou non, émanant des établissements d'enseignement et de recherche français ou étrangers, des laboratoires publics ou privés. 


\title{
Triggering of Volcanic Pulses in the Campanian Area, South Italy, by Periodic Deep Magma Influx
}

\author{
MARTINE PATERNE AND FRANCOIS GUICHARD \\ Centre des Faibles Radioactivités, Laboratoire mixte CNRS/CEA, Domaine du CNRS, Gif sur Yvelte, \\ France
}

\begin{abstract}
Geochemical fluctuations through time of the eruptions originating from Ischia island and from the Phlegrean Fields in the Campanian area have been analyzed in order to determine the relationships between the mechanisms responsible for compositional variations of the magmas and the fluctuations in eruptions. Geochemical fluctuations are derived from the detailed chronological and geochemical record of marine tephra in deep-sea sediment cores from the central Mediterranean Sea. Such fluctuations are marked by the repetition of similar compositional gradients during each eruptive cycle, as defined by a period of intense activity followed by a quiet eruptive period. Geochemical changes through time in both areas may be explained by magma evolution in a continuously crystallizing, tapped, and periodically refilled stratified magma chamber. Each eruptive and geochemical cycle starts by an influx of magma from depth into the shallow reservoirs, which leads to an increase in the frequency of the eruptions and maintains the activity in a particular volcanic area. This inflow may be controlled by changes of glacio-eustatic pressure, as suggested by its periodic occurrence every $24 \mathrm{kyr}$.
\end{abstract}

\section{INTRODUCTION}

Several causes for the fluctuations in eruptive rates in volcanic areas have been advanced, such as changes of rates of sea-floor spreading [Kennett et al., 1977], solar activity [Stothers, 1989], lunar attraction [Dzurizin, 1980] and climatic changes [Rampino et al., 1979; Matthews, 1969; Walcott, 1972; Kennett and Thunell, 1975]. Pressure variations on mantle would mechanically facilitate magma ascent through the lithosphere in response to changes in Earth's rotation, leading to readjustment of the rate of motion of the Earth's interior, and/or to changes in the distribution of water masses during Quaternary glaciations [Matthews, 1969; Walcott, 1972; Rampino et al., 1979; Stothers, 1989]. Magma inflow from a deeper source into shallow reservoirs may produce an overpressure that is able to trigger an eruption, as has been observed during periods of inflation of some volcanoes prior to eruption. Such an influx of undifferentiated magma from depth would modify the geochemical evolution of residual evolved liquids within shallow magma chambers which is mainly controlled by fractional crystallisation [O'Hara, 1977; O'Hara and Matthews, 1981; Albarède, 1985]. Thus relationships between magma influx and eruptivity may be analysed by recording changes in the geochemical composition of erupted products through time and the fluctuations of the volcanic activity.

Temporal series of the explosive activity of the Campanian volcanoes has been developed for the past $190 \mathrm{kyr}$ by detailed chronological and geochemical studies of marine ash layers of 5 deep-sea cores from the Tyrrhenian and Adriatic seas (Figure 1). Analysis of the frequency of the eruptions through time shows that eruptive cycles of aboul $23 \mathrm{kyr}$ occur during this time period [Paterne et al., 1990]. In this study, we have used the major and trace element composition of the Campanian ash layers to examine process of magma evolution. As

Copyright 1993 by the American Geophysical Union. fractional crystallisation cannot entirely explain the observed geochemical trends through time, mixing processes either within a zoned magma chamber or during the filling of a shallow reservoir with magma from depth have been explored with respect to variations of relative erupted masses estimated for each eruption. Finally, the influence of such processes on the changes in rates of eruptions through time have been analysed.

\section{METHODS}

Methods of stratigraphical and geochemical identification of marine tephra layers, each one accounted for a unique eruptive event, have been previously published [Paterne et al., 1986; 1988; 1990]. Major and trace element analyses were performed on glass shards, which are the only volcanic materials in marine sediments that can be traced over long distances. Furthermore, vitreous particles are representative of the magmatic liquid, its composition varying along with crystallisation, mixing or contamination processes.

Major element compositions, measured at $15 \mathrm{kV}, 0.3 \mathrm{nA}$ on large areas $\left(20\right.$ to $50 \mu^{2}$ ) for $100 \mathrm{~s}$ with a Scanning Electron Microscope (SEM) coupled with an X ray Energy Dispersion Spectrometer (EDS) have been obtained on individual glass shards. Means and standard deviations have been calculated for each ash layer and some examples are given in Table 1. Each event, as defined by a chronostratigraphical position and by a chemically homogeneous composition has a mean value given in Tables 2 and 3 with a standard deviation which corresponds to a $2 \%$ error on $\mathrm{SiO}_{2}, 5 \%$ on $\mathrm{Al}_{2} \mathrm{O}_{3}$, and $20 \%$ on the other elements.

Trace element compositions were obtained by neutron activation analysis. Pure glasses, with crystal contents lower than 5\%, separated from chemically homogeneous tephra layers were irradiated with a flux of $10^{14} \mathrm{n} / \mathrm{cm}^{2} / \mathrm{s}$ for 5 to 20 min. in $\mathrm{Al}$ vials and quartz tubes at the Centre d'Etudes Nucléaires of Saclay. Chemical measurements were made using an intrinsic Ge detector of $80 \mathrm{~cm}^{3}$, using granite and basalt 


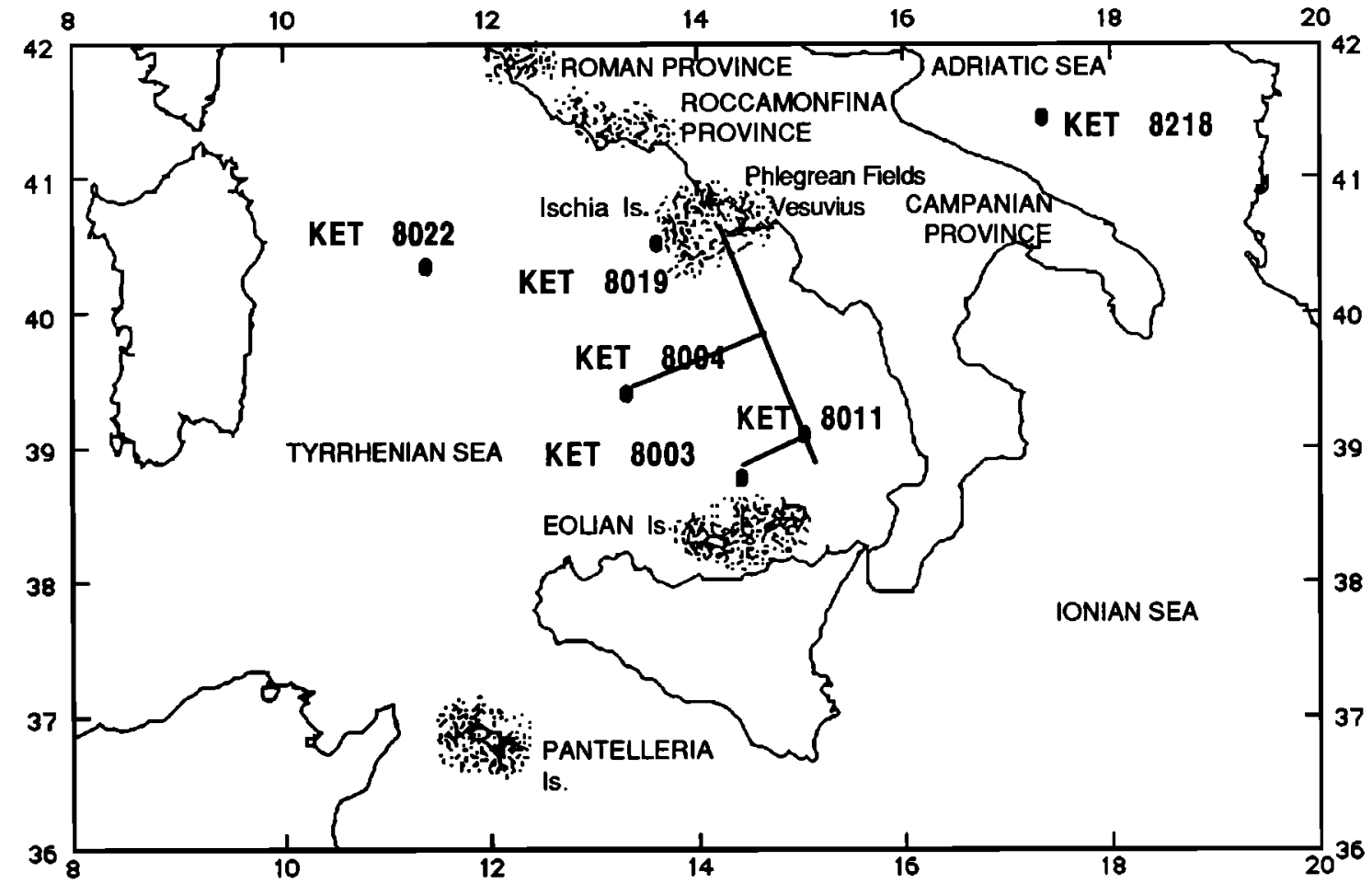

Fig. 1. Location of the deep-sea cores and of the volcanic areas (shaded) of southem Italy. See text for explanations of the lines connecting marine cores.

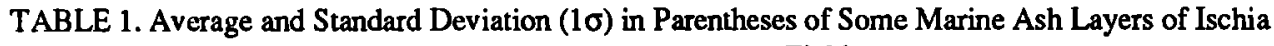
Island and of the Phlegrean Fields

\begin{tabular}{|c|c|c|c|c|c|c|}
\hline \multicolumn{7}{|c|}{ Ash layer } \\
\hline & $70-04$ & C-16 & $C(\mathrm{i})-6$ & $690-04$ & C-7 & $\mathrm{C}-10$ \\
\hline No* & 21 & 53 & 20 & 20 & 43 & 42 \\
\hline $\mathrm{SiO}_{2}$ & $63.36(0.31)$ & $61.63(0.93)$ & $64.37(1.08)$ & $62.27(0.64)$ & $63.12(0.90)$ & $60.4 \quad(0.55)$ \\
\hline $\mathrm{TiO}_{2}$ & $0.6(0.13)$ & $0.31 \quad(0.09)$ & $0.13(0.13)$ & $0.56(0.07)$ & $0.25(0.08)$ & $0.23(0.11)$ \\
\hline $\mathrm{Al}_{2} \mathrm{O}_{3}$ & $18.97(0.26)$ & $19.09(0.22)$ & $18.55(0.07)$ & $19.05(0.22)$ & $18.53(0.21)$ & $20.02(0.41)$ \\
\hline $\mathrm{FeO}$ & $2.74(0.42)$ & $2.97(0.47)$ & $2.39(0.22)$ & $2.68(0.13)$ & $3.03(0.39)$ & $2.69(0.41)$ \\
\hline $\mathrm{MgO}$ & $0.11(0.07)$ & $0.14(0.07)$ & $0.01 \quad(0.02)$ & $0.09(0.05)$ & $0.14(0.13)$ & $0.04(0.06)$ \\
\hline $\mathrm{CaO}$ & $0.95(0.03)$ & $1.84(0.29)$ & $1.56(0.16)$ & $1 \quad(0.09)$ & $2.17(0.33)$ & $3.15(0.36)$ \\
\hline $\mathrm{Na}_{2} \mathrm{O}$ & $6.47(0.70)$ & $6.27(0.49)$ & $4.99(0.99)$ & $7.81(0.73)$ & $3.86(0.52)$ & $4.38(0.54)$ \\
\hline $\mathrm{K}_{2} \mathrm{O}$ & $6.76(0.19)$ & $7.72(0.54)$ & $7.98(0.42)$ & $6.5 \quad(0.28)$ & $8.86(0.42)$ & $9.05(0.24)$ \\
\hline Age kyr & 8.9 & 51 & 57.2 & 65 & 26.9 & 33.5 \\
\hline
\end{tabular}

The ash layers are either numbered, or noted by their level of depth, followed by the two last numbers of the cores.

*The number of analyzed glass shards.

rocks standards (GSN and BEN) from the CRPG (Centre de Recherches Pétrographiques et Géochimiques de Nancy). Analytical precision is $10 \%$ for $\mathrm{Sc}, \mathrm{Co}, \mathrm{Zr}, \mathrm{Cs}, \mathrm{La}, \mathrm{Ce}, \mathrm{Sm}$. $\mathrm{Eu}, \mathrm{Tb}, \mathrm{Yb}, \mathrm{Hf}, \mathrm{Ta}$, and $\mathrm{Th} ; 15 \%$ for $\mathrm{Cr}, \mathrm{Sb}, \mathrm{Ba}, \mathrm{Nd}$ and $\mathrm{Lu}$ and $20 \%$ for $U$.

Trace element analyses could not be performed on all marine ash layers because of the small sample sizes of some tephra or because of geochemical heterogeneity, mainly due to bioturbation [Paterne et al., 1988]. Detailed analyses of the major element composition of all ash layers are presented elsewhere [Paterne, 1985], and only major and trace element data obtained on the same tephra are given in Tables $2 a, 2 b$ and 3 .

\section{MAGMA EVOLUTTON}

Trace element pattems of the ash layers were compared with the compositions of pure glass shards from continental 
TABLE 2a. Major and Trace Element Analyses of Marine Ash Layers Originated from Ischia Island

\begin{tabular}{|c|c|c|c|c|c|c|c|c|c|c|c|c|c|c|c|c|}
\hline \multicolumn{17}{|c|}{ Ash layer } \\
\hline & 5-19 & $70-04$ & $142-04$ & C-3 & C-5 & $35 \mathrm{M}$ & 104 & $260-04$ & $C(i)-5$ & C-11 & $\mathrm{C}-13$ & $460-04$ & $\mathrm{C}-14$ & C-15 & $\mathrm{C}-16$ & C-17 \\
\hline$\overline{\mathbf{N}_{0} *}$ & 20 & 21 & 20 & 18 & 14 & & & 19 & 15 & 31 & 64 & 30 & 15 & 30 & 53 & 47 \\
\hline $\mathrm{SiO}_{2}$ & 63.60 & 63.36 & 63.09 & 65.20 & 63.43 & 60.72 & 52.6 & 64.86 & 62.22 & 61.6 & 62.05 & 62.04 & 63.02 & 61.35 & 61.63 & 62.97 \\
\hline $\mathrm{TiO}_{2}$ & 0.55 & 0.6 & 0.52 & 0.27 & 0.33 & 0.66 & 1.36 & 0.34 & 0.36 & 0.28 & 0.35 & 0.27 & 0.35 & 0.29 & 0.31 & 0.41 \\
\hline $\mathrm{Al}_{2} \mathrm{O}_{3}$ & 17.73 & 18.97 & 19.36 & 17.98 & 19.02 & 19.32 & 18.69 & 18.48 & 19.10 & 19.31 & 19.32 & 19.5 & 18.98 & 19.13 & 19.09 & 18.79 \\
\hline FeO & 2.51 & 2.74 & 2.64 & 2.34 & 2.11 & & & 2.79 & 2.95 & 2.95 & 2.75 & 2.55 & 2.23 & 3.06 & 2.97 & 2.53 \\
\hline $\mathrm{MnO}$ & 0.21 & - & - & - & - & 0.1 & 0.14 & - & & & & $\therefore$ & - & & & - \\
\hline $\mathrm{MgO}$ & 0.60 & 0.11 & 0.2 & 0.00 & 0.42 & 0.84 & 3.25 & 0.05 & 0.00 & 0.13 & 0.13 & 0.16 & 0.08 & 0.13 & 0.14 & 0.05 \\
\hline $\mathrm{CoO}$ & 1.26 & 0.95 & 0.99 & 1.38 & 1.3 & 2.51 & 7.52 & 0.91 & 1.92 & 1.79 & 1.63 & 1.68 & 1.28 & 1.95 & 1.84 & 1.5 \\
\hline $\mathrm{Na}_{2} \mathrm{O}$ & 6.36 & 6.47 & 6.59 & 5.83 & 6.07 & 5.13 & 3.61 & 6.5 & 5.94 & 5.67 & 6.12 & 6.19 & 7.56 & 6.52 & 6.27 & 6.86 \\
\hline $\mathrm{K}_{2} \mathrm{O}$ & 6.57 & 6.76 & 6.57 & 6.65 & 7.31 & 6.9 & 3.89 & 6.03 & 7.47 & 8.23 & 7.61 & 756 & 6.47 & 7.53 & 7.72 & 6.85 \\
\hline Sc & 3.29 & 2.09 & 2.64 & 1.27 & 3.7 & 3.8 & 20 & 1.61 & 3.04 & 3.3 & 2.3 & 3 & 5.6 & 2.5 & 2.4 & 4 \\
\hline $\mathrm{Cr}$ & 24.5 & 7 & 12.6 & 11.3 & 12 & 5 & 11 & & - & & 6.4 & 9.5 & 41 & 9 & 29 & - \\
\hline Co & 3.3 & 1.1 & 2.05 & 2.4 & 62 & 11.4 & 22 & 12 & 4.1 & 4.2 & 2.6 & 3.3 & 7.5 & 3 & 3.5 & 7 \\
\hline $\mathrm{Ni}$ & 17 & & & & & & & 26 & 21 & & & & 12 & & & \\
\hline $\mathbf{R b}$ & 334 & 399 & 520 & 454 & 546 & 240 & 106 & 503 & 305 & 286 & 929 & 427 & 144 & 315 & 300 & 298 \\
\hline $\mathrm{Sr}$ & 75.5 & 126 & 407 & 62.3 & 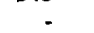 & 294 & 711 & & 187 & 282 & 98 & 110 & 177 & 135 & 104 & 207 \\
\hline $\mathbf{Z r}$ & 456 & 446 & 680 & 816 & 1070 & 260 & 165 & 920 & 425 & 372 & 470 & 698 & 173 & 460 & 424 & 358 \\
\hline $\mathbf{S b}$ & 0.69 & & & 2.28 & 2.5 & - & - & 2.07 & 0.9 & & & 2.15 & 0.59 & 1.34 & 1.32 & 1.22 \\
\hline Cs & 22.2 & 29.5 & 41.36 & 48.5 & 48.52 & 1.8 & 5 & 50.9 & 22 & 21.5 & 28.9 & 41.8 & 10.81 & 24.85 & 21.87 & 16.34 \\
\hline $\mathrm{Ba}$ & 194 & 225 & 351 & 340 & 307 & 433 & 1350 & 345 & 284 & 455 & 277 & 279 & 335 & 280 & . & 347 \\
\hline $\mathrm{L}_{\mathbf{a}}$ & 76 & 98 & 134 & 128 & 159 & 58 & 42 & 145 & 89 & 78 & 108 & 146 & 60 & 104 & 87 & 70 \\
\hline $\mathrm{Ce}$ & 167 & 188 & 250 & 260 & 308 & 95 & 97 & 279 & 179 & 159 & 219 & 288 & 73 & 208 & 165 & 157 \\
\hline $\mathbf{N d}$ & 61 & 50 & 6 & 71 & 79 & 63 & 45 & 69 & 59.5 & 53 & 70 & 92 & 25 & 63 & 56 & 48 \\
\hline $\mathrm{Sm}$ & 10.8 & 10 & 11.7 & 12 & 12.7 & 8.2 & 8 & 12.5 & 10.4 & 9.2 & 12.8 & 16. & 6.7 & 13. & 11.6 & 8.9 \\
\hline $\mathrm{Eu}$ & 1.3 & 0.88 & 1.76 & 1.16 & 0.7 & 0.9 & 2.8 & 0.82 & 1.55 & 1.5 & 1.6 & 1.25 & 0.7 & 1.7 & 1.6 & 1.8 \\
\hline $\mathrm{Tb}$ & 1.1 & 1 & 1.2 & 1.25 & 1.5 & 0.96 & 0.9 & 1.16 & 1.19 & 0.92 & 1.09 & 1.76 & 0.4 & 1.24 & 1.07 & 1.09 \\
\hline $\mathrm{Yb}$ & 4.4 & 4.72 & 8.4 & 5.43 & 8.38 & 0.94 & 2.5 & 6.91 & 3.77 & 3.5 & 4.6 & 6.29 & 1.83 & 4.27 & 3.75 & 3.28 \\
\hline Lu & 0.75 & 0.93 & 1.27 & 0.93 & 1.4 & 0.2 & 0.51 & 1.3 & 0.62 & 0.52 & 0.66 & 1.01 & 0.28 & 0.7 & 0.57 & 0.52 \\
\hline $\mathrm{Hf}$ & 11.03 & 13.68 & 20.4 & 18.3 & 25.1 & 5.7 & 3.9 & 22.2 & 9.9 & 8.7 & 13 & 17.4 & 4.7 & 11 & 9.6 & 8.5 \\
\hline $\mathbf{T a}$ & 5.59 & 5.35 & 6.5 & 6.22 & 7.67 & 3.3 & 1.9 & 6.05 & 4.5 & 4.56 & 5.5 & 8.35 & 1.77 & 5.42 & 4.55 & 3.91 \\
\hline Th & 40.5 & 50.9 & 77.6 & 83.3 & 105.8 & 20.1 & 9.5 & 84.3 & 36.3 & 32.1 & 44.3 & 65.72 & 12.8 & 40.5 & 36.4 & 27.4 \\
\hline $\mathrm{U}$ & 12.9 & 16.3 & 21.8 & 28.4 & 30.8 & 4.9 & 2.5 & 26.6 & 11.78 & 9.5 & 17.9 & 23.5 & 5.4 & 15.56 & 12 & 8.38 \\
\hline Age kyt & $\underset{\mathrm{C}}{4.35}$ & 8.9 & 13.9 & $\stackrel{14.4}{\mathrm{C}^{*}}$ & $\begin{array}{c}19.62 \\
\mathrm{~B} 1\end{array}$ & $\begin{array}{r}23.6 \\
\mathrm{~A} 1\end{array}$ & $\begin{array}{r}28.1 \\
\text { A1 }\end{array}$ & $\begin{array}{r}26.4 \\
\text { D2 }\end{array}$ & 35.2 & $\begin{array}{r}36.6 \\
\text { C2 }\end{array}$ & $\stackrel{40}{\mathrm{C}^{*}}$ & $\begin{array}{c}40.5 \\
\text { B2 }\end{array}$ & $\begin{array}{l}41.8 \\
\text { A2 }\end{array}$ & $\begin{array}{r}46.7 \\
\text { D3 }\end{array}$ & 51 & $\begin{array}{r}55.4 \\
\text { C } 3\end{array}$ \\
\hline
\end{tabular}

The ash-layers are either numbered, or noted by their level of depth, followed by the two last numbers of the cores. Alphabetic numbering of the ash layers referred to their position in the geochemical cycle. See Text.

* Number of analyzed glass shards.

deposits and with published whole rock analyses (Figure 2) [Poli et al., 1987, 1989; Villemant, 1988; Crisci et al., 1989]. As noted previously [Paterne et al., 1988], trace element patterns of marine tephra follow similar trend as the continental ones. Thus, the marine environment has not played a significant role in the alteration of vitric particles during the time sequence considered.

Source regions of the Campanian tephra have been previously deduced from the comparison between the alkali ratios in marine and land deposits [Paterne, 1985; Paterne et al., 1988]. Products that were derived from Ischia island have a lower $\mathrm{K}_{2} \mathrm{O} / \mathrm{Na}_{2} \mathrm{O}$ ratio than products of the Phlegrean Fields, which are relatively enriched in $\mathrm{K}_{2} \mathrm{O}$ (Tables 2 and 3 ). In marine ash layers, the activity of the Phlegrean Ficlds is represented by trachytes (Table 3), one trachybasaltic and one latitic ash layer [Paterne, 1985]. No marine tephra of phonolitic composition has been found, but continental deposits of such a composition are very scarce in this area [Armienti et al., 1983]. Nevertheless, marine ash layers reflect the full range of composition [Villemant, 1988], matching the weight abundance of the different chemical groups observed in the Phlegrean Fields on land [Armienti et al., 1983]. Products of Ischia island are only represented by peralkalic trachytes in marine ash layers, which is strongly consistent with field observations which showed that the full range of composition from trachybasalt to phonolite is only observed in the lava flows of the recent phase of activity [Poli et al., 1987, 1989].

Processes of magma evolution have been analysed using the behavior of hygromagmaphile elements [Treuil and Varet,
1973; Allègre et al., 1977; Allègre and Minster, 1978]. In Phlegrean Fields tephra, the highest enrichment factors, characterizing hygromagmaphile elements, are observed for $\mathrm{U}$, $\mathrm{Cs}, \mathrm{Rb}, \mathrm{Th}$ and $\mathrm{Ta}$, and in the products of Ischia island for $\mathrm{Th}$, $\mathrm{Zr}, \mathrm{Ce}, \mathrm{U}, \mathrm{Hf}$. Correlation diagrams between some of hygromagmaphile elements and of compatible elements, using Th as a reference element because of its low mineral/liquid partition coefficient, are shown in Figure 3. In the Phlegrean Fields, magmatic evolution is clearly related to a fractional crystallization process, as demonstrated by the linear correlations between incompatible elements through a continuous and single trend crossing the origin and by the rapid decrease of the transition series elements, such as $\mathrm{Sc}$ and $\mathrm{Cr}_{\mathrm{r}}$, with differentiation. Magmatic evolution processes are relatively difficult to trace within the products of Ischia island because of their high degree of differentiation (two tephralayers in the range 10 to $20 \mathrm{ppm}$ of $\mathrm{Th}$ ), and because the bulk partition coefficient varies with differentiation. Nevertheless, a fractional crystallization process may be envisaged, taking into account the trachybasalts present on the island [Poli et al., 1987].

Furthermore, marine ash layers from both the Phlegrean Fields and Ischia island show one single continuous trace element trend (Figures 2 and 3), suggesting that these magmas are derived from fractional crystallization of similar parental liquid(s). The different behavior of some elements, particularly the strong decoupling of compatible and incompatible elements in Ischia products, which is not observed in those of the Phlegrean Fields (Tables 2 and 3), indicates that magmatic 
TABLE 2b. Major and Trace Element Analyses of Marine Ash Layers Originated from Ischia Island

\begin{tabular}{|c|c|c|c|c|c|c|c|c|c|c|c|c|c|c|c|}
\hline & \multicolumn{15}{|c|}{ Ash layer } \\
\hline & $C(\mathrm{i})-6$ & $457-11$ & C-18 & $644-04$ & $654-04$ & $690-04$ & $717-04$ & $745-04$ & 855-04 & $920-04$ & $958-04$ & 968-04 & $985-04$ & $1290-04$ & $1410-04$ \\
\hline$\overline{\mathbf{N}_{0} *}$ & 20 & 20 & 25 & 11 & 25 & 20 & 15 & 16 & 42 & 19 & 15 & 12 & 29 & 29 & 26 \\
\hline $\mathrm{SiO}_{2}$ & 64.37 & 62.64 & 62.78 & 64.52 & 62.57 & 62.27 & 62.38 & 63.47 & 62.44 & 63.21 & 62.89 & 62.38 & 62.18 & 63.7 & 64.25 \\
\hline $\mathrm{TiO}_{2}$ & 0.13 & 0.56 & 0.48 & 0.47 & 0.57 & 0.56 & 0.44 & 0.69 & 0.44 & 0.55 & 0.35 & 0.36 & 0.33 & 0.64 & 0.64 \\
\hline $\mathrm{Al}_{2} \mathrm{O}_{3}$ & 18.55 & 19.28 & 18.56 & 18.13 & 18.79 & 19.05 & 19.37 & 18.73 & 18.99 & 18.45 & 18.92 & 18.71 & 18.66 & 18.67 & 18.44 \\
\hline $\mathrm{FeO}$ & 2.39 & 2.54 & 2.59 & 2.58 & 3.09 & 2.68 & 2.54 & 3.03 & 2.61 & 2.71 & 2.87 & 3.02 & 2.97 & 2.61 & 2.54 \\
\hline MnO & - & - & - & - & - & - & - & - & - & - & - & - & - & - & - \\
\hline $\mathrm{MgO}$ & 0.01 & 0.13 & 0.07 & 0.05 & 0.02 & 0.09 & 0.04 & 0 & 0.05 & 0.07 & 0.05 & 0.05 & 0.1 & 0.05 & 0.02 \\
\hline $\mathrm{CaO}$ & 1.56 & 1.1 & 1.32 & 1.24 & 1.23 & 1 & 1.41 & 1.27 & 1.02 & 1.2 & 1.82 & 1.76 & 1.84 & 0.9 & 1 \\
\hline $\mathrm{Na}_{2} \mathrm{O}$ & 4.99 & 7.44 & 7.45 & 6.15 & 6.94 & 7.81 & 7.28 & 5.75 & 8.28 & 7.64 & 6.33 & 6.98 & 6.64 & 7.23 & 6.7 \\
\hline $\mathrm{K}_{2} \mathrm{O}$ & 7.98 & 6.27 & 6.71 & 6.81 & 6.75 & 6.5 & 6.49 & 7.04 & 6.15 & 6.15 & 6.73 & 6.69 & 7.25 & 6.18 & 6.37 \\
\hline $\mathrm{Sc}$ & 2 & 2.41 & 2.5 & 2.91 & 2.3 & 1.87 & 3 & 2 & 2.08 & 5.4 & 2.75 & 2.32 & 4.1 & 3.3 & 2.7 \\
\hline $\mathrm{Cr}$ & 5 & 16 & 23 & 7 & 8 & 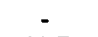 & 27 & - & 8 & 29 & 13 & 14 & 13 & 25 & 7 \\
\hline Co & 2 & 1.9 & 3 & 2 & 3 & 11.7 & 4 & 1 & 1.4 & 3 & 4 & 2.9 & 7 & 6 & 5 \\
\hline $\mathbf{N i}$ & - & 18 & - & 14 & - & 16 & 11 & - & - & - & 25 & 24 & 0.19 & - & - \\
\hline $\mathbf{R b}$ & 363 & 316 & 341 & 307 & 356 & 377 & 205 & 420 & 349 & 383 & 347 & 456 & 254 & 359 & 320 \\
\hline $\mathrm{Sr}$ & 52 & 207 & 119 & 90.5 & 58 & & 231 & - & 71 & 179 & 276 & - & 306 & 70 & 28 \\
\hline $\mathbf{Z} \boldsymbol{r}$ & 510 & 416 & 485 & 413 & 386 & 602 & 263 & 601 & 648 & 652 & 647 & 849 & 447 & 605 & 509 \\
\hline Sb & 0.74 & 0.82 & 0.8 & 0.76 & 1 & 1.57 & 0.56 & & 1.03 & 1.6 & 1.4 & 2.1 & 1.49 & - & 1 \\
\hline Cs & 21.56 & 17.7 & 20.93 & 17.66 & 19.84 & . & 13.99 & 33.01 & 22.8 & 24.6 & 25.76 & 36.9 & 20.24 & 20.8 & 17.83 \\
\hline $\mathrm{Ba}$ & 197 & 233 & 217 & 275 & 37 & 149 & 340 & 233 & 219 & 293 & 420 & 257 & 513 & 96 & 35 \\
\hline $\mathrm{La}$ & 118 & 95 & 108 & 89 & 103 & 135 & 52 & 165 & 147 & 140 & 142 & 174 & 114 & 132 & 137 \\
\hline $\mathrm{Ce}$ & 223 & 198 & 222 & 187 & 175 & 259 & 101 & 322 & 267 & 292 & 301 & 447 & 205 & 233 & 294 \\
\hline $\mathbf{N d}$ & 73 & 68 & 75 & 67 & 90 & 103 & 34 & 89 & 84 & 88 & 88.5 & 154 & 71 & 76 & 87 \\
\hline Sm & 12.5 & 11 & 15.4 & 11.9 & 15.1 & 16.3 & 6.1 & 16.4 & 15.1 & 13.4 & 16.8 & 20 & 11.2 & 15.2 & 15.2 \\
\hline Eu & 1 & 1.22 & 1.3 & 1.27 & 1.2 & 1.01 & 1.1 & 1 & 1.1 & 1.2 & 2.2 & 2.2 & 1.6 & 1.2 & 1.3 \\
\hline $\mathrm{Tb}$ & 1.62 & 1.27 & 1.44 & 1.06 & 1.57 & 1.49 & 0.63 & 2.06 & 1.68 & 1.69 & 1.7 & 2.27 & 1.21 & 1.33 & 1.47 \\
\hline Yb & 5.22 & 4.49 & 4.67 & 4.1 & 5.21 & 6.3 & 2.63 & 7.7 & 6.28 & 6.23 & 5.92 & 7.4 & 4.33 & 5.47 & 5.77 \\
\hline $\mathrm{Lu}$ & 1.13 & 0.73 & 0.8 & 0.66 & 0.78 & 1.11 & 0.38 & 1.22 & 1.01 & 1.07 & 0.82 & 1.45 & 0.74 & 0.81 & 0.93 \\
\hline $\mathrm{Hf}$ & 13 & 10.8 & 11.8 & 10.4 & 11.9 & 15.5 & 6.25 & 19.7 & 16.5 & 17.7 & 13.5 & 19.3 & 9.8 & 14.3 & 12.7 \\
\hline$T \mathbf{a}$ & 5.01 & 4.54 & 5.08 & 4.35 & 5.51 & 6.92 & 2.31 & 7.18 & 5.91 & 5.62 & 5.72 & 8.14 & 3.75 & 4.49 & 4.15 \\
\hline Th & 37.8 & 32.1 & 35.7 & 32.5 & 29.7 & 52.2 & 19.5 & 64.3 & 52.7 & 59.4 & 54.2 & 77.3 & 37.5 & 62.3 & 52.9 \\
\hline $\mathrm{U}$ & 11.5 & 9.45 & 10.86 & 10.6 & 8.41 & 16.8 & 6.9 & 16.3 & 16 & 16.8 & 16.3 & 19.5 & 13.45 & 14.8 & 14.1 \\
\hline Age ky & 57.2 & 58.9 & 60.3 & 60.7 & $\begin{array}{r}62.2 \\
C^{*}\end{array}$ & $\begin{array}{l}65 \\
B 3\end{array}$ & $\begin{array}{l}68.5 \\
\text { A3 }\end{array}$ & $\begin{array}{c}76.5 \\
D 4\end{array}$ & $\begin{array}{c}93.7 \\
\text { C4 }\end{array}$ & 100.6 & $\begin{array}{r}104.5 \\
C^{*}\end{array}$ & $\begin{array}{c}105.8 \\
B 4\end{array}$ & $\begin{array}{c}107.3 \\
\text { A4 }\end{array}$ & 155.1 & 186.6 \\
\hline
\end{tabular}

The ash-layers are either numbered, or noted by their level of depth, followed by the two last numbers of the cores. Alphabetic numbering of the ash layers referred to their position in the geochemical cycle. See Text.

* Number of analyzed glass shards.

evolution in both areas has taken place within different reservoir systems.

\section{GEOCHEMICAL FLUCTUATIONS THROUGH TTME}

Magma evolution trends through time, as recorded by the marine tephra, are first compared with continental volcanic records, and then with fluctuations in the frequency of eruptions. Variations in thorium concentrations with time are thus reported for tephra originating from Ischia island in Figure 4, since this element is highly hygromagmaphile and is relatively insensitive to alteration. Because of the small number of trace element data obtained on glass shards in marine tephra from the Phlegrean Fields, we report the $\mathrm{SiO}_{2}$ values through time (Figure $5 \mathrm{~d}$ ), as $\mathrm{SiO}_{2}$ has a similar behavior to that of thorium.

Comparison of the volcanic records in Ischia island shows that the amplitude of the thorium variations is similar, with the exception of one event at $108 \mathrm{ppm}$ in the marine record, but thorium concentrations are slightly higher in marine ash layers than in land samples [Poli et al., 1987; 1989]. This may be due to crystal abundance in the analysed land samples, including lavas, which tends to decrease thorium concentrations. Nevertheless, the main features of magma evolution are preserved throughout time. The time span, ranging from $110 \mathrm{kyr}$ to nearly $60 \mathrm{kyr}$, is much better documented in marine ash layers than on land. During the past $20 \mathrm{kyr}$, both marine and land data are strongly consistent, defining a decrease of thorium concentration. Counterpart of the lava flows, which show depleted thorium concentrations in the land record at around $25 \mathrm{kyr}$, have not been found in marine ash layers because this type of activity cannot be recorded in the marine sediments. Therefore, the sharp $T h$ increase, which occurred between $35 \mathrm{kyr}$ to $20 \mathrm{kyr}$ in the marine ash layers, is constrained by land data to occur between $25 \mathrm{kyr}$ and $20 \mathrm{kyr}$ [Poli et al., 1987, 1989]. The land samples of trachybasaltic composition will be further taken into account in the geochemical marine record. Finally, from 55 to $35 \mathrm{kyr}$, the marine ash layers show two repetitive oscillations, each one marked by increasing and decreasing trends from 55 to $42 \mathrm{kyr}$ and from 42 to $35 \mathrm{kyr}$. Similar features may be observed in compositional variations of land samples, but, on land, the age of the maximum thorium concentration during the second oscillation from 42 to $35 \mathrm{kyr}$ does not coincide with that of the marine record. However, the age of this land deposit is estimated from stratigraphical relationship between two dated 
TABLE 3. Major and Trace Element Analyses of Marine Ash Layers Originated From the Phlegrean Fields

\begin{tabular}{|c|c|c|c|c|c|c|c|}
\hline & & & & $\mathrm{h}$ layer & & & \\
\hline & C-1 & $120-18$ & C-2 & $C-4$ & C-7 & C-10 & C-9 \\
\hline$\overline{\mathbf{N}_{0} *}$ & 32 & 23 & 20 & 17 & 43 & 42 & 19 \\
\hline $\mathrm{SiO}_{2}$ & 59.86 & 60.5 & 61.94 & 52.32 & 63.12 & 60.4 & 66.16 \\
\hline $\mathrm{TiO}_{2}$ & 0.44 & 0.3 & 0.31 & 1.45 & 0.25 & 0.23 & 0.24 \\
\hline $\mathrm{Al}_{2} \mathrm{O}_{3}$ & 19.78 & 19.23 & 19.63 & 18.44 & 18.53 & 20.0 & 27.82 \\
\hline $\mathrm{F}=0$ & 3.46 & 3.72 & 2.99 & 7.86 & 3.03 & 2.69 & 1.98 \\
\hline $\mathrm{MnO}$ & & & - & - & & & \\
\hline $\mathrm{MgO}$ & 0.37 & 0.07 & 0.2 & 4.4 & 0.14 & 0.04 & 0.04 \\
\hline $\mathrm{CaO}$ & 2.76 & 3.32 & 1.99 & 8.18 & 2.17 & 3.15 & 2.26 \\
\hline $\mathrm{Na}_{2} \mathrm{O}$ & 3.58 & 3.98 & 4.34 & 4.27 & 3.86 & 4.38 & 3.6 \\
\hline $\mathrm{K}_{2} \mathrm{O}$ & 9.72 & 8.83 & 8.57 & 3.08 & 8.86 & 9.05 & 7.85 \\
\hline Sc & 4.16 & 4.8 & 4.57 & 30.4 & 3.1 & 1.7 & 1.8 \\
\hline $\mathrm{Cr}$ & 37 & 30.5 & 21.5 & 91 & 10 & 8.75 & \\
\hline Co & 7 & 5.5 & 4.05 & 34 & 4.2 & 8.7 & 8.3 \\
\hline $\mathrm{Ni}$ & & 25 & 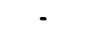 & & & 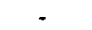 & \\
\hline $\mathbf{R b}$ & 258 & 223 & 237 & 85 & 675 & - & 359 \\
\hline Sr & 804 & 659 & 510 & 714 & 253 & 601 & 350 \\
\hline $\mathrm{Zr}$ & 271 & 206 & 278 & 143 & 298 & 305 & 364 \\
\hline$\overline{S b}$ & 0.76 & 0.56 & 0.37 & 0.38 & & 0.45 & 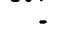 \\
\hline Cs & 16.7 & 12 & 14.5 & 3.01 & 17.9 & 21 & 30.48 \\
\hline Ba & 1661 & 800 & 720 & 744 & 301 & 676 & 376 \\
\hline La & 52 & 44 & 74 & 23 & 60 & 78 & 70 \\
\hline Ce & 108 & 90 & 106 & 123 & 120 & 153 & 136 \\
\hline $\mathbf{N d}$ & 38 & 31.5 & 42.4 & 26 & 41 & 49 & 44 \\
\hline $\mathrm{Sm}$ & 7.2 & 6 & 8.6 & 5.6 & 7.2 & 8.9 & 7.7 \\
\hline Eu & 1.7 & 1.8 & 1.5 & 2 & 1.6 & 2 & 1.6 \\
\hline $\mathrm{Tb}$ & 0.68 & 0.64 & 0.7 & 1.06 & 0.6 & 0.82 & 0.74 \\
\hline $\mathrm{Yb}$ & 1.97 & 1.94 & 2.68 & 2.1 & 2.55 & 2.97 & 3.3 \\
\hline Lu & 0.37 & 0.31 & 0.48 & 0.36 & 0.42 & 0.48 & 0.48 \\
\hline Hf & 6.4 & 5.7 & 6.52 & 3.2 & 7.5 & 7.2 & 8.4 \\
\hline $\mathrm{Ta}$ & 2.46 & 2.32 & 2.6 & 0.95 & 2.72 & 3.1 & 2.94 \\
\hline Th & 23 & 18.9 & 23.3 & 6 & 26.6 & 32.2 & 36.8 \\
\hline U & 7.47 & 7.93 & 8.09 & 1.08 & 8.4 & 10.18 & 13 \\
\hline Age kyr & 9.76 & 11.4 & 12.3 & $\begin{array}{l}19.62 \\
\mathrm{Al}\end{array}$ & 26.9 & 33.5 & 36 \\
\hline
\end{tabular}

The ash-layers are either numbered, or noted by their level of depth followed by the two last numbers of the cores. Alphabetic numbering of the ash layers referred to their position in the geochemical cycle. See Text.

* Number of analyzed glass shards.

marker deposits [Poli et al., 1989]. Thus an age closer to 40 kyr for this event is not incompatible taking into account the stratigraphical relationships and dating of those products. Thus land and marine compositional records do not show incompatible features, and the good consistency of the different compositional trends through time both in continental and marine volcanic sequences exclude any sampling artefact in the marine environment.

In the Phlegrean Fields, the compositional variations indicate a trachytic to trachybasaltic trend for the past $10 \mathrm{kyr}$ [Armienti et al., 1983] that is consistent with the magma evolution observed from the marine tephra data (Figure 5d). The similar trend from 37 to $20 \mathrm{kyr}$, as recorded by marine tephra, has not been observed on land, as products erupted during this time span are not exposed because of caldera collapse [Armienti et al., 1983; Barberi et al., 1978; Rosi et al., 1983].

Statistical analysis of the timing of the eruptions in the Campanian area provided eruptive cycles of a nearly $23 \mathrm{kyr}$ periodicity for the past $190 \mathrm{kyr}$ [Paterne et al., 1990]. Variations of the frequency of eruptions of the Phlegrean Fields and on Ischia island have been obtained using a sliding window $8 \mathrm{kyr}$ wide, and have been separated in order to compare geochemical and eruptive fluctuations in each area through time (Figures $5 \mathrm{a}$ and $5 \mathrm{c}$ ). Each eruptive cycle is defined by an increase in the number of eruptions followed by a period of relatively quieter activity. Transitions between active and quiet periods are marked by low $\mathrm{Th}$ and $\mathrm{SiO}_{2}$ eruptions (A). Each volcanic pulse is then underlined by a period of increasing concentrations, followed by a decreasing one, respectively limited by points $B$ and $C$. Finally, during each period of quiet activity, concentrations increase until point $D$ and return to $\mathrm{A}$ along the decreasing compositional trend DA. Thus, rates of eruption and changes of their composition do not seem to be related since both quiet and active periods show similar geochemical fluctuations. However, during each eruptive cycle, compatible elements such as $\mathrm{Sc}, \mathrm{Co}, \mathrm{Cr}$ have a different behavior along the similarly decreasing $\mathrm{Th}$ concentrations in Ischia island, since their concentration increases during the DA path while it remains nearly constant during BC (Tables 2 and 3). Furthermore, the enrichment rates, expressed as the ratio of the concentrations of thorium and of $\mathrm{SiO}_{2}$ from one eruption to the preceeding event (Table 4), are negatively correlated with the time span between eruptions as they are higher after a smaller time span (step AB) than after a larger one (step $C D$ ). Thus, although similar geochemical trends are observed with both qiuet and active periods during each eruptive cycle, they cannot be explained by the same geophysical cause as they are marked by a different behavior of the elements.

Repetition of similar fluctuations of the compositional gradients through time within each eruptive cycle in both areas strengthens the reliability of the data obtained on the marine ash layers, since only a very selective sampling could give such a scheme of geochemical changes. Moreover, such fluctuations through time cannot be explained by a simple fractional crystallisation evolution, and mixing processes must be further envisaged.

\section{TRACING MAGMA INFLUX FROM DEPTH}

Mixing of an incomming undifferentiated liquid from depth with more evolved residual liquids of a magma chamber will result in a negative compositional gradient in volcanic time sequences. But such gradients have been commonly observed within pyroclastic deposits, their temporal composition varying from highly differentiated to more mafic magmas (negative concentration gradient), which reproduces the zonation within the reservoir (for rewiews see: Hildreth [1981], Fischer and Schmincke [1984], and McBirney [1985]) Such compositional variations, ranging typically from $2 \%$ to $5 \%$ for $\mathrm{SiO}_{2}$ for a single eruption [Hildreth, 1981; Baker and McBirney, 1985] may occur within Campanian events, but cannot be detected in the marine record according to the standard deviation obtained on the mean composition of the glass shards. In the Campanian time series, negative compositional gradients may only be observed if magma discharge increases leading to the mixing of highly differentiated upper levels with less evolved bottom levels of the zoned magma chamber [Spera et al., 1989; Blake andFink, 1987; Carrigan and Eichelberger, 1990; Sigurdsson et al., 1990] because of the time spans between eruptions during which fractional crystallisation continuously proceeds.

Erupted volumes have not been directly investigated from field studies, except for the two very large eruptions of the Napolitan Yellow tuff and the Campanian Ignimbrite which occurred in the Phlegrean Fields, with volumes of $10 \mathrm{~km}^{3}$ and $80 \mathrm{~km}^{3}$, respectively [Barberi et al., 1978; Armienti et al., 1983]. Although large masses of volcanic particles may be 

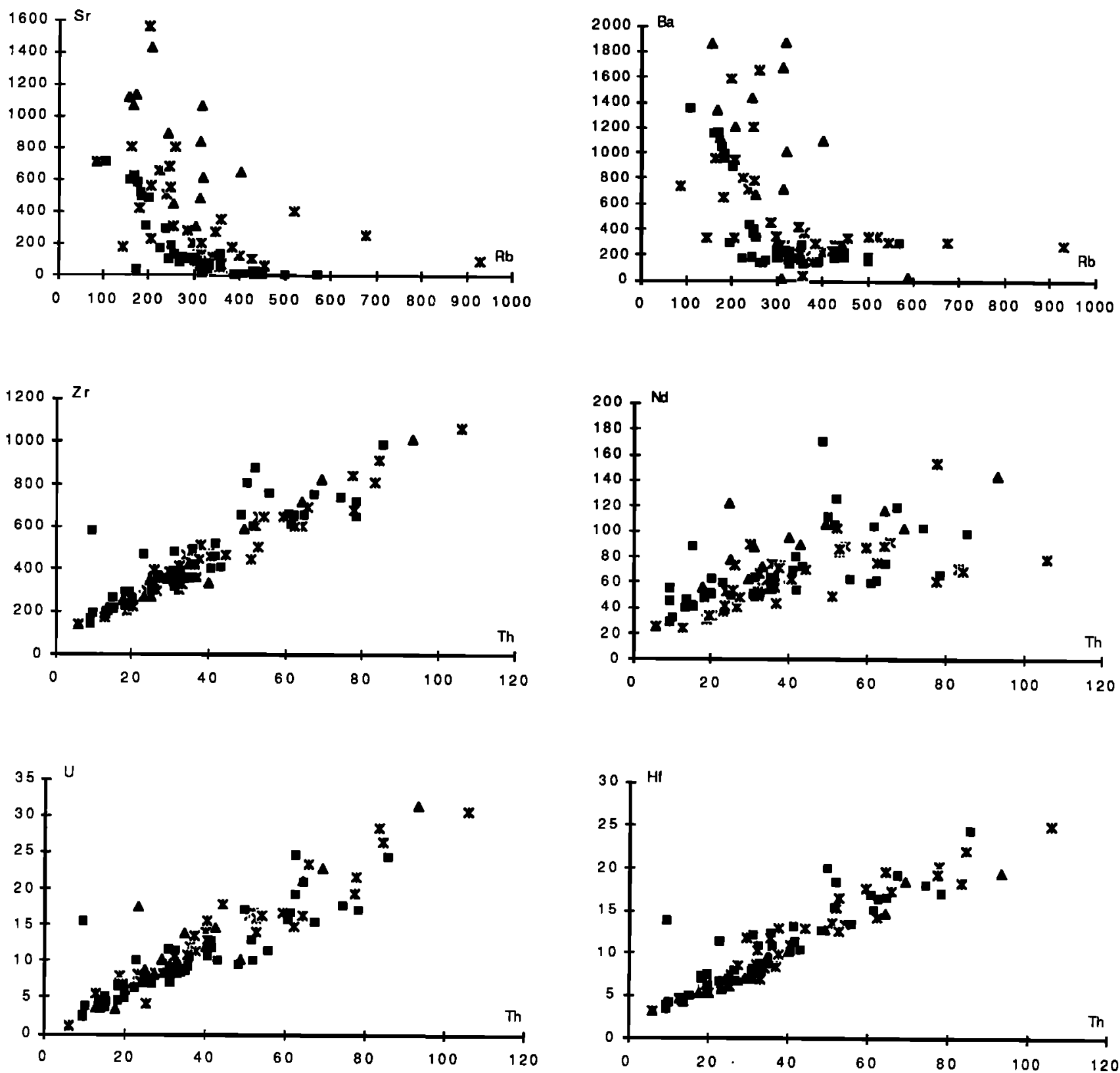

Fig. 2. Comparison of the geochemical composition of marine tephra (crosses) and of the Phlegrean Fields (triangles) and Ischia island (squares) subaerial volcanics. Concentrations are expressed in ppm.

dispersed by the winds over broad areas [Sparks and Walker, 1977], eruption volumes cannot be directly estimated from marine ash layers since the main parts of the deposits are continental. The aerial dispersal of the volcanic particles is controlled by the column hcight, and the higher the eruption column height, the larger the mass ouput [Carey and Sigurdsson, 1989]. Thus, considering a similar wind strength for all the eruptions, the larger the erupted mass, the larger the observed one in the same site situated on the dispersal axis of the eruption, at a constant distance from the source area. We have estimated the relative masses of erupted products by weighing the total dried sediment and sieving it at $40 \mu$ in all the cores, except core KET 8019. Then the weight of the coarser volcanic fraction for each eruption has been obtained after decalcification, and expressed in $g$ of the coarser fraction per $1 \mathrm{~g}$ of sediment. Such masses have been integrated over the total thickness of the ash layers, which can range from some millimeters to some tens of centimeters. As the larger weights are generally found in core KET 8004 (Figures 6a and 6b), this site has been considered as the reference situated at a distance of about $150 \mathrm{Km}$ from the source area (Figure 1). However, for some eruptions, larger masses of volcanic material are observed in the most distant core KET 8011 suggesting that this core is nearest to, or is situated on the dispersal axis of the volcanic cloud. In those cases, rough mass calculations have been made in order to compare the detrital fraction which would be observed at the same distance as KET 8004 . Considering that the detritic fraction increases linearly from site KET 8003 to site KET 8011, we have used a similar coefficient from site KET 8004 to this dispersal axis. The obtained relative masses $M$ are shown as a function of time on Figures $6 a$ and $6 b$. They are generally very small, except for the ash layers previously 

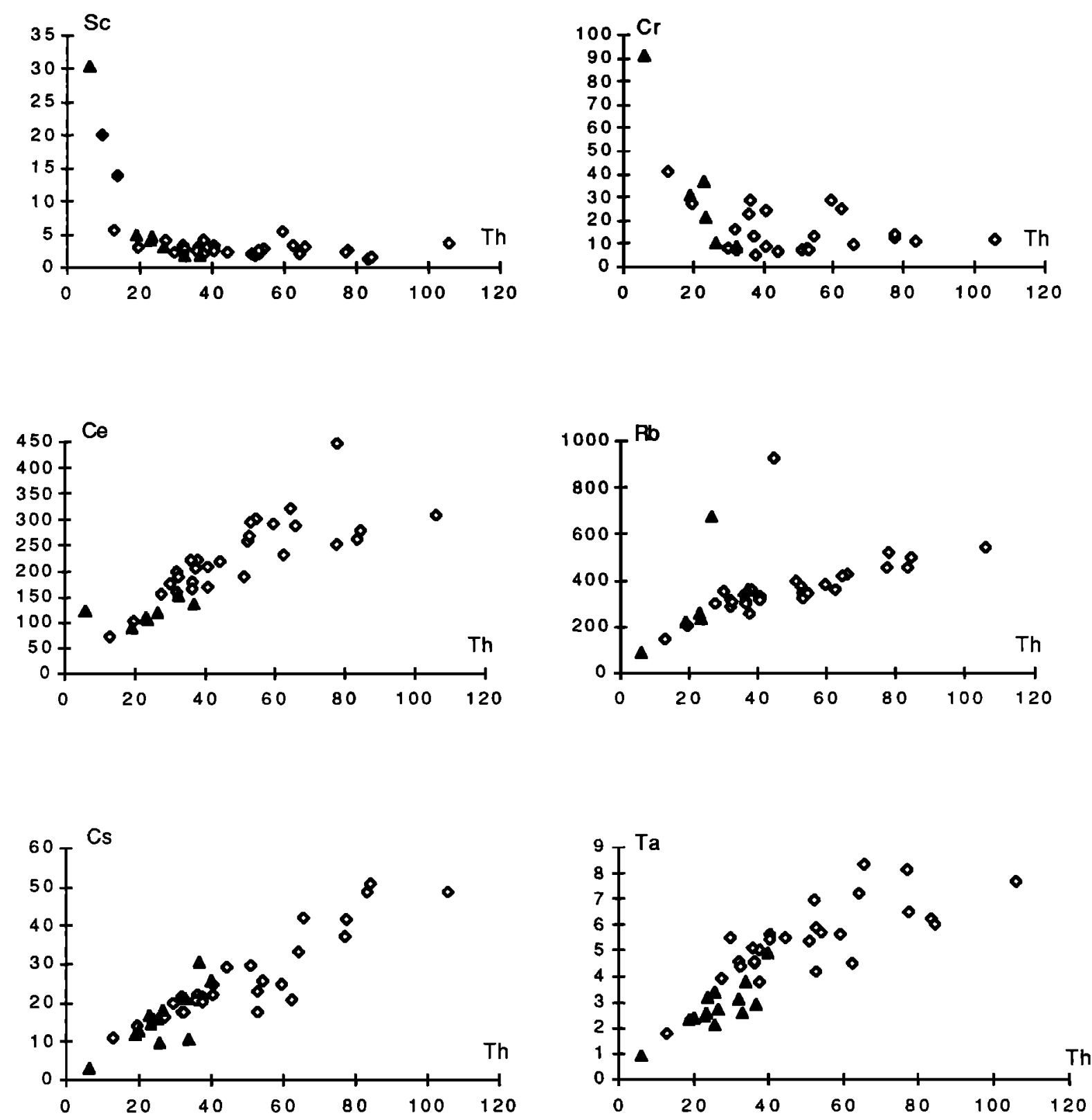

Fig. 3. Correlation diagram between some compatible and incompatible elements in marine ash layers from the Phlegrean Fields (triangles) and from Ischia Island (diamonds). Concentrations are expressed in ppm. Trachybasaltic lavas from Ischia island dated by the K/Ar method [Poli et al., 1987] are indicated as solid diamonds.

related to the Campanian Ignimbrite and the Neapolitan Yellow Tuff [Paterne et al., 1986], which are considered as the largest eruptions in the Phlegrean Fields [Barberi et al., 1978; Armienti et al., 1983]. Relative mass estimates, obtained on marine tephra from Ischia island, demonstrate that the largest eruptions are related the Green tuff of Mount Epomeo and the Citara formation (Figure 6b), as it has been observed from field investigations [Forcella et al., 1983; Poli et al., 1987, 1989]. In the Ischia area, some other eruptions have apparent masses above the background, occurring at $14.4 \mathrm{kyr}, 62.3 \mathrm{kyr}$ and $93.7 \mathrm{kyr}$, which have not been related to continental deposits.

In both the Phlegrean Fields and Ischia island, the larger volume events preferentially occur during the negative compositional gradient BC (Figures 6a, 6b), either at C* immediately after eruption $B$ and/or at $C$ at the end of this trend. The relative mass, erupted during the event $B$ is lower than that produced during the following eruption $C^{*}$, which underlines the decrease of thorium concentrations. Thus, the depleted concentrations observed at $\mathrm{C}^{*}$ may be explained by an increase in magma discharge with respect to $B$, allowing the mixing of upper and lower layers of highly to less differentiated products within continuously crystallising zoned reservoirs. Furthermore, caldera formation, as observed in the Phlegrean Fields consecutively to the huge eruption of the Campanian Ignimbrite at $33.5 \mathrm{kyr}$ (point $\mathrm{C}$ in Figure 6b), does not favor the hypothesis of large refilling of the reservoir at this time. A similar mechanism cannot be envisaged for the DA depletion since the erupted masses in A are very small (Figures $6 \mathrm{a}$ and $6 \mathrm{~b}$ ), the related trachybasalts being lava flows or pyroclastic deposits of small extent and volume both in the 


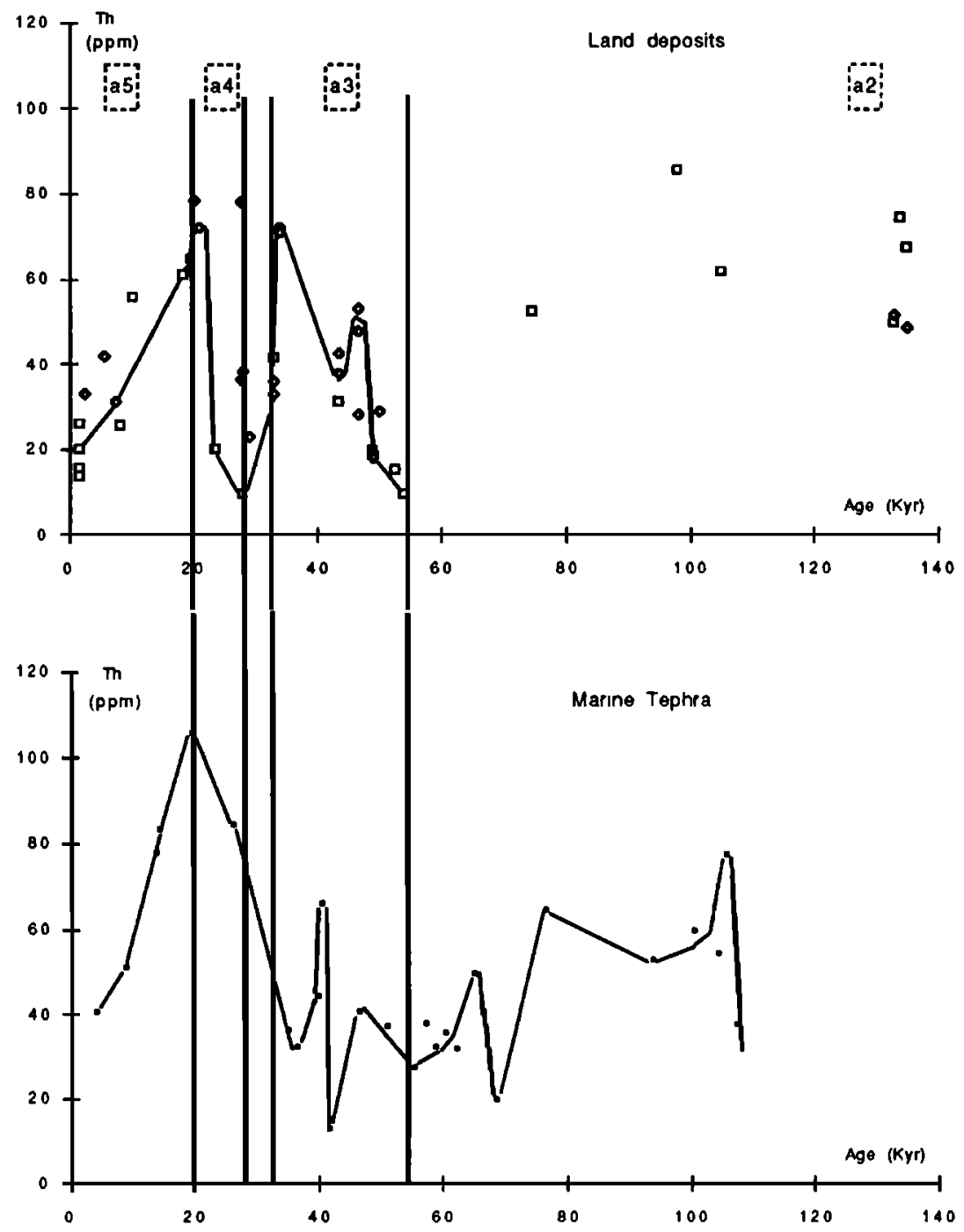

Fig. 4. Fluctuations of thorium concentrations of the volcanic products from Ischia island versus time, as recorded by land deposits, either directly dated (squares) or stratigraphically estimated (diamonds) [Poli et al., 1987; 1989] and by marine tephra.

Phlegrean Fields and on Ischia island [Barberi et al., 1978; Forcella et al., 1983; Poli et al., 1987, 1989]. Thus, eruption $A$ is explained by the opening of the reservoirs, its geochemical composition resulting from the mixing of residual liquid with an incomming undifferentiated liquid from depth. Inflow of deep magma into the reservoir during the DA path would allow the increase of the highly compatible elements such as $\mathrm{Ni}, \mathrm{Cr}, \mathrm{Co}$ and $\mathrm{Sc}$ while the mixing of differentiated layers of a stratified magma chamber along the $\mathrm{BC}$ path would have little effect on compatible elements as it can be deduced from the relation of $\mathrm{Sc}$ or $\mathrm{Cr}$ versus $\mathrm{Th}$ (Figure 3). Then geochemical fluctuations may be explained by changes of rates of magma discharge in a stratified magma reservoir while fractional crystallisation proceeds until a new refilling and a new geochemical cycle occur.

The behavior of elements in such a model, in which outflow of the most depleted liquids occurs prior to fractionation, has been theoretically analysed [Albarede, 1985] and very strong enrichments of incompatible elements with moderate depletions of compatible elements are predicted in such open reservoirs with respect to closed systems, taking into account small sizes of crystallised fraction and of erupted liquids. Considering a liquid of homogeneous composition $A$ and using the equation developed by Albarède [1985], the 2 to 11 enrichment rates of thorium observed along step AB in Ischia tephra (Table 4) would correspond to either erupted volumes (Y) of $1 \%$ to $0.1 \%$ respectively of the magma chamber with $1 \%$ fractionation $(\mathrm{X})$, or to $10 \%$ to $1 \%$ of fraction $\mathrm{Y}$ with $10 \%$ fractionation. Such fractionation rates are more compatible with the abundance of crystals in the pyroclastic deposits, as observed either on Ischia island or in the Phlegrean Fields [Armienti et al., 1983] than the required crystallisation rates for the same enrichments in a closed sytem, ranging from $50 \%$ to more than $80 \%$. Such small crystallisation rates and predicted volumes of erupted products will have little effect on the concentrations of major elements [O'Hara and Matthews, 1977;1981; Albarede, 1985], as observed in Ischia deposits. Such a decoupling is not observed within the deposits of the Phlegrean Fields (Table 3), likely because of the huge volumes of expelled pyroclastic deposits, such as the Campanian 

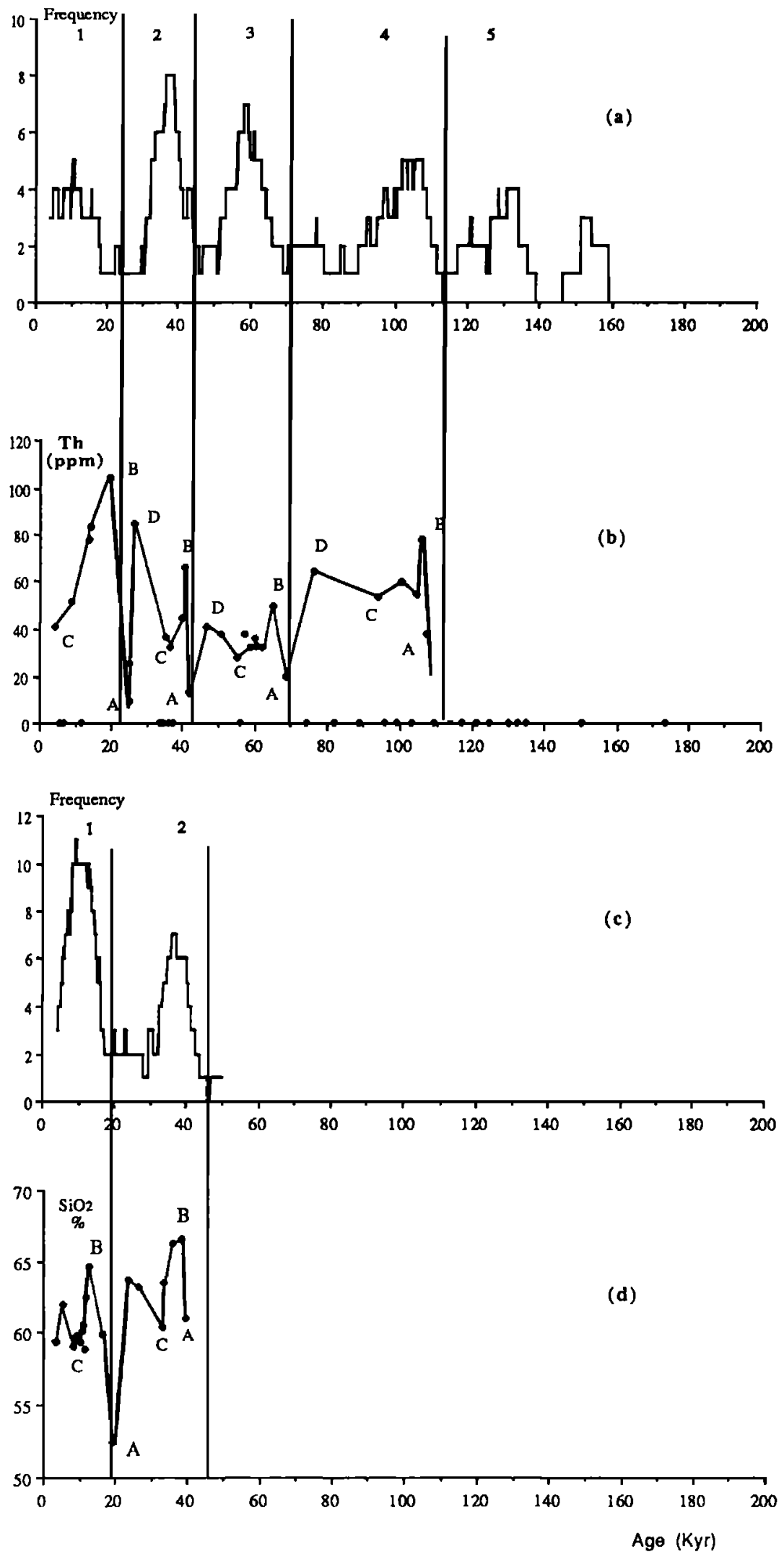

Fig. 5. Variations of the frequency of enuptions as a function of time, as recorded by marine tephra (a) from Ischia island and (c) from the Phlegrean Fields, using a 8 kyr width sliding window. Fluctuations (b) of thorium concentrations in Ischia island products and (d) of $\mathrm{SiO}_{2}$ composition in Phlegrean Fields deposits. Points on the $\mathrm{X}$ axis refer to marine ash-layers of unanalysed trace element composition. Circled numbers refer the numbers of the eruptive cycles. 
TABLE 4. Enrichment/Depletion Rates During the Positive and Negative Compositional Paths for Each Eruptive Cycle in Ischia Island and in the Phlegrean Fields

\begin{tabular}{|c|c|c|c|c|c|c|c|c|c|c|c|c|}
\hline \multirow{3}{*}{$\begin{array}{l}\text { Paths } \\
\text { A-B }\end{array}$} & \multicolumn{6}{|c|}{ Ischia island } & & & \multicolumn{4}{|c|}{ Phlegrean Fields } \\
\hline & \multicolumn{2}{|c|}{ Cycle 1} & \multicolumn{2}{|c|}{ Cycle 2} & \multicolumn{2}{|c|}{ Cycle 3} & \multicolumn{2}{|c|}{ Cycle 4} & \multicolumn{2}{|c|}{ Cycle 1} & \multicolumn{2}{|c|}{ Cycle 2} \\
\hline & 11.10 & (5.4) & 5.10 & (1.3) & 2.70 & (3.5) & 2.10 & (1.5) & 1.23 & (6.4) & 109 & (2.7) \\
\hline B-C1 & 0.80 & (5.2) & 0.70 & (3.9) & 0.57 & $(6.3)$ & 0.70 & (1.3) & 0.91 & (1.4) & 0.91 & (5.2) \\
\hline C-D & - & & 2.60 & $(10.2)$ & 1.48 & (8.7) & 1.22 & (17.2) & - & & 1.05 & (9.4) \\
\hline DA & - & & 0.11 & (1.4) & 0.32 & $(4.9)$ & - & & - & & 0.82 & (4.5) \\
\hline
\end{tabular}

The duration of each trend is given in kyr in the parentheses.
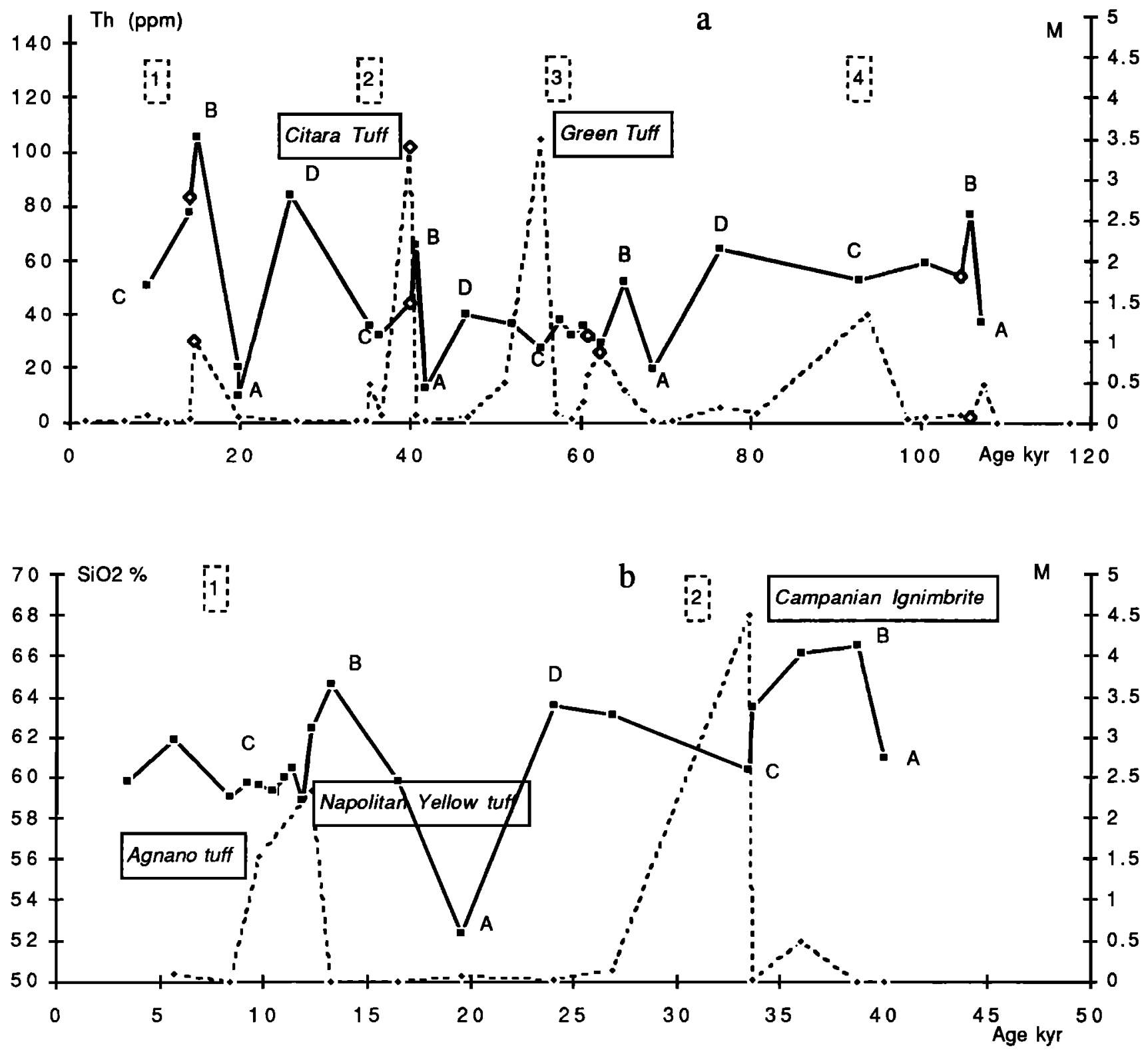

Fig. 6. Comparison of the relative mass abundance (M) (solid diamonds) on the left axis through time of the ash layers originated (a) from Ischia island and (b) from the Phlegrean Fields with the thorium and $\mathrm{SiO}_{2}$ concentrations (squares) on the right axis. Event $C^{*}$ is indicated as (open diamonds). (see text for explanation). 
Ignimbrite $\left(80 \mathrm{~km}^{3}\right)$, after which a large caldera collapse occurred, or such as the Napolitean Yellow tuff $\left(10.5 \mathrm{~km}^{3}\right)$ [Barberi et al., 1978; Armienti et al., 1983].

Since major and trace element analyses were performed on pure glass shards, which reflect liquid composition, geochemical behavior of the source of deep magma has been traced through time by the analysis of ratios of incompatible elements which would be constant as crystal fractionation proceeds with liquids of similar origin. On Ischia island, the $\mathrm{La}$, Ta or $\mathrm{Zr}$ versus Th ratios are constant from the past until about $26 \mathrm{kyr}$ (Figure 7), suggesting that processes of crystallisation and refilling of magma chamber by a magma inflow of similar origin dominate along this time span. Then, they change during the most recent phase of activity, suggesting the arrival from depth of a geochemically distinct magma in the reservoir. $\mathrm{Sr}$ and $\mathrm{Nd}$ isotope measurements, performed on continental deposits [Civetta et al., 1991], show similar features. At around $28 \mathrm{kyr}, \mathrm{Sr}_{\mathrm{r}}$ isotope values show a sharp change from 0.7068 to 0.70608 , related to arrival of a new geochemically distinct magma. From around $10 \mathrm{kyr}$ to Recent, related to the $\mathrm{BC}$ path in the marine tephra record (Figure 5), Sr isotope values decrease to 0.7058 and then progressively increase to 0.70626 , that has been interpreted as a new refilling with a distinct magma at $10 \mathrm{kyr}$ and then as a progressive tapping of an isotopically stratified magma chamber [Civelta et al., 1991]. However, the considered refilling of the magma chamber at $10 \mathrm{kyr}$ does not coincide with a decrease of incompatible elements such as $\mathrm{Th}, \mathrm{Zr}$ and $\mathrm{La}$, as it is the case at $28 \mathrm{kyr}$ [Civetta et al., 1991]. So that, we suggest that one geochemical cycle occurs from $28 \mathrm{kyr}$ to Recent, starting by the refilling of the reservoir with a distinct magma, and then that the augmentation of expulsed masses at around $10 \mathrm{kyr}$ with respect to the preceeding eruptions, as observed in marine tephra, would facilitate the mixing and the sutflow of isotopically different magmas.

\section{OCCURRENCE OF DEFP MAGMA INFL OW THROUGH TIME}

Each inflow occurs simultaneously in both magma chambers of the Phlegrcan Fields and Ischia island, taking into account errors in datings (Figure 5) and it coincides uniquely to the beginning of enhanced rate of eruption. This suggests that volcanic pulses are triggered by this energy supply. Then, frequency of eruptions decreases as a function of time until a new refilling occurs, allowing the extent of the life time of volcanic areas.

Frequency of this refilling has been analysed over the best documented time span from the past $110 \mathrm{kyr}$, using the Blackman-Tukey and Maximum Entropy spectral analyses developped by Petiaux and Berger [1982; 1984], which allow a better estimates of the amplitude and a higher resolution of the frequency peaks respectively. As elemental composition changes with respect to fractional crystallisation processes and to variations of the rates of magma discharge, spectral analyses of the geochemical changes through time have been performed on the Sc/Ta ratio record in order to take into account geochemical fluctuations due to magma influx (Figure 8 ). Both methods show a peak of frequency corresponding to about $24 \mathrm{kyr}$, expressed at a $95 \%$ confidence level by the Blackman-Tukey method, which is similar to that of the fluctuations of the frequency of the number of eruptions through time [Paterne et al., 1990]. The occurrence of such a periodicity in the marine tephra record of magma inflow though time excludes strongly sedimentary processes in the marine environment as a cause of such geochemical variations, the geochemical composition of the marine tephra being not tied to their stratigraphical position along the cores.

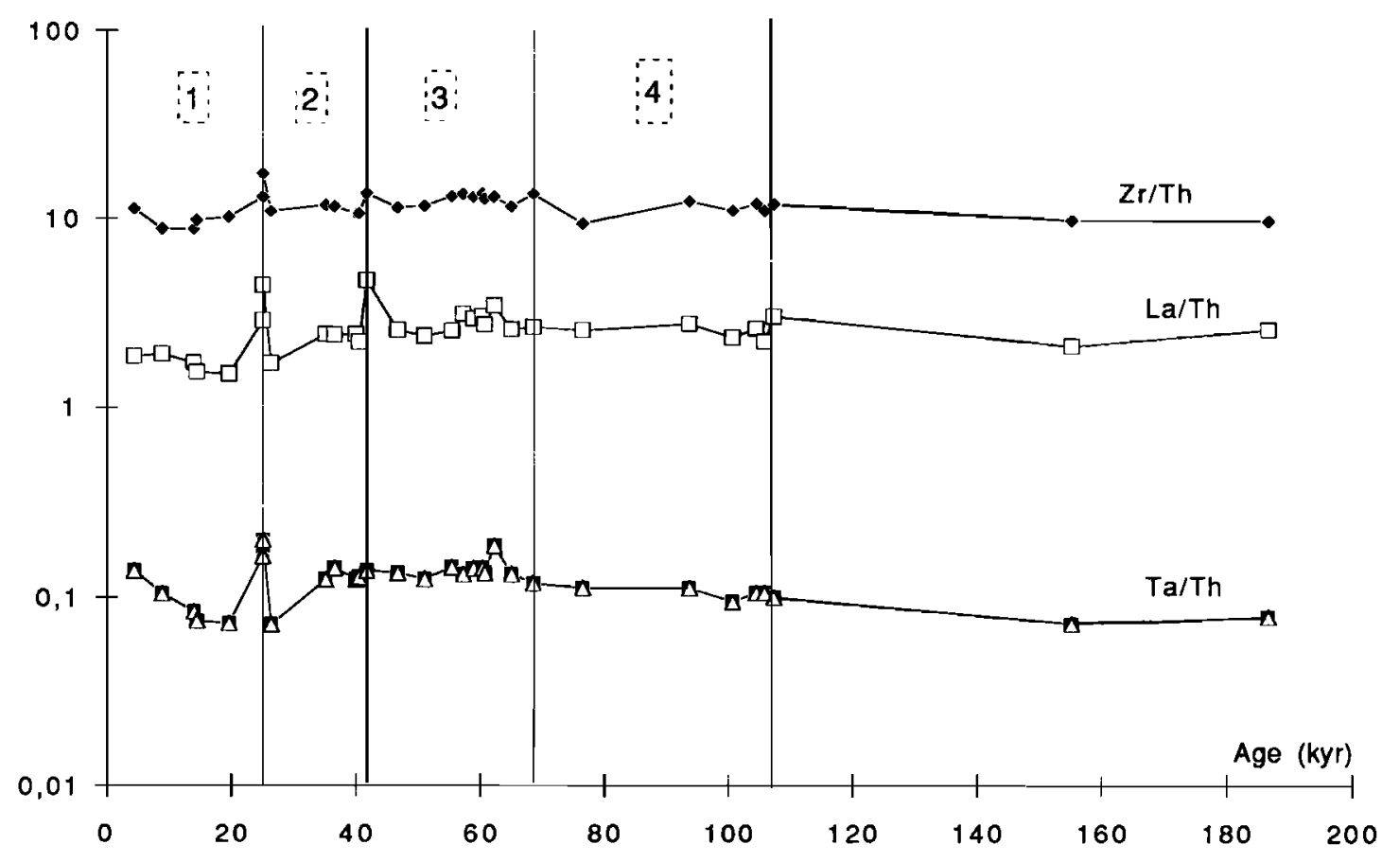

Fig. 7. Logarithmic variations of the $\mathrm{Ta} / \mathrm{Th}, \mathrm{La} / \mathrm{Th}$ and $\mathrm{Zr} / \mathrm{hh}$ as a function of time in $\mathrm{kyr}$. Numbers are referred to eruptive cycle numbering. 

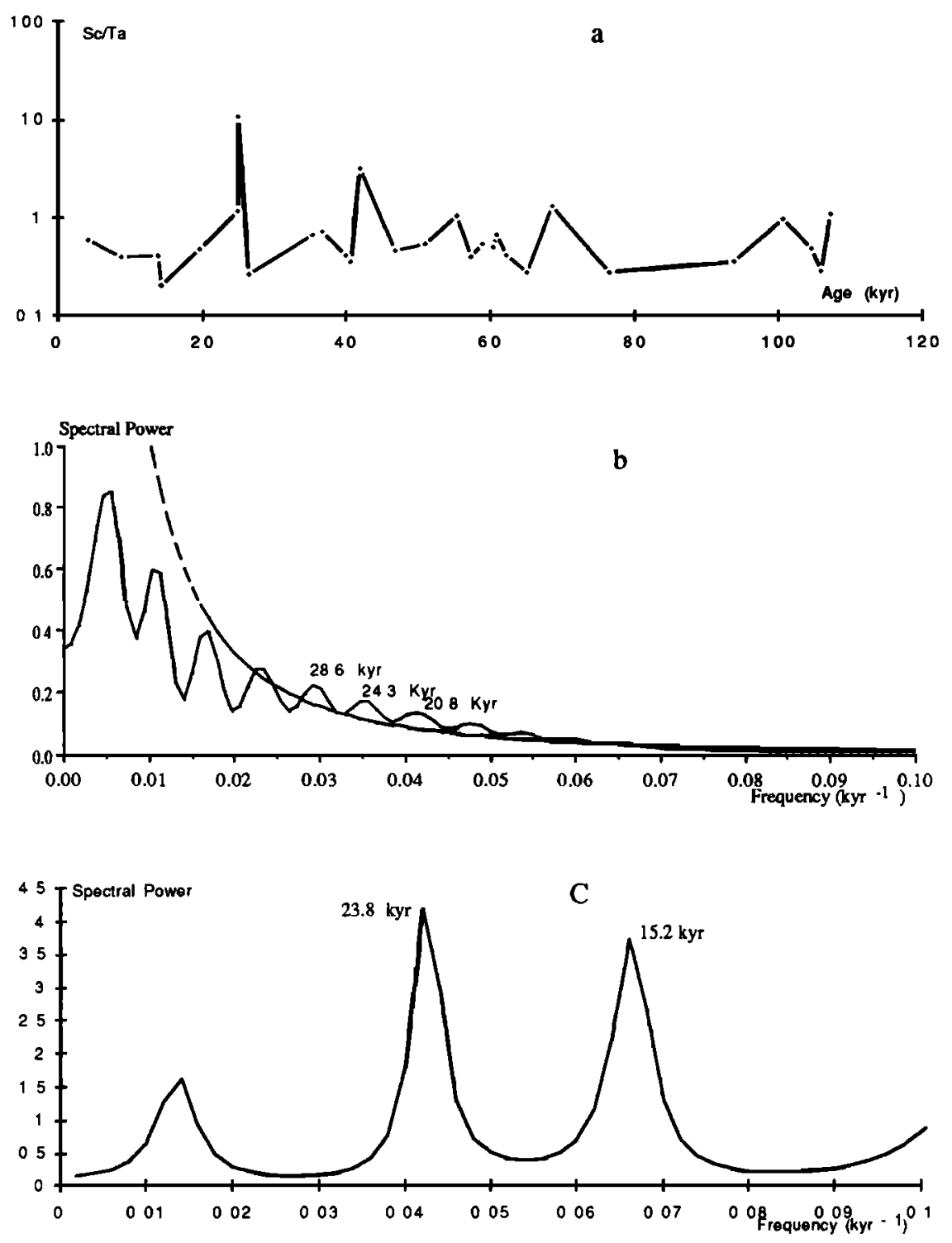

Fig. 8. (a) Logarithmic variations of the $\mathrm{Sc} / \mathrm{Ta}$ ratio as a function of time. Power spectra over $110 \mathrm{kyr}$ of curve a following the methods described by Petiaux and Berger [1982,1984], after linear detrending (b) by the Blackman-Tukey method with a 95\% confidence level and (c) by Maximum Entropy .

The periodicity of inflow of magma from depth is very similar to that of the precession of Earth's orbit which leads to variations of the solar radiation budget through time and to changes in ice and water loads during Quaternary glaciations. Thus, although other hypotheses cannot be excluded aside, glacio-eustatic pressure changes, related to the lowering of sea level in the volcanic area, coupled to ice cap loading, as previously suggested [Matthews, 1969; Walcott, 1972; Chappell, 1975; Rampino et al., 1979] may have facilitated magma ascent into the shallow reservoirs.

\section{SUMMARY AND CONCLUSIONS}

A detailed time series of the geochemical changes of the Campanian events has been developed by marine tephrochronology. Such a reconstruction is strongly consistent with previous field studies of the temporal geochemical fluctuations [Poli et al., 1987, 1989; Civetta et al., 1991] and is better documented for the most ancient volcanic activity.

Geochemical fluctuations in marine ash layers through time, as well as in the Phlegrean Fields and on Ischia Island, show repetitive changes in compositional gradients, related to eruptive cycles. Each geochemical cycle starts with an injection of hotter magma from a deeper source, the composition of which may vary, which triggers an eruptive period, as defined by increase of the number of eruptions. The frequency of the eruptions then decreases until a new refilling occurs which contributes to extend the life time of a volcanic area. During each eruptive and geochemical cycle, the geochemical trends may be explained by changes in the rate of magma discharge in a compositionally zoned reservoir which is continuously crystallising and periodically refilled.

Refillings of the shallow reservoirs occur with a periodicity of about $24 \mathrm{kyr}$, similar to that of the frequency of the number of eruptions through time [Paterne et al., 1989]. Because the 
geochemical composition of the marine tephra are not tied to their chronostratigraphical position in deep-sea sediments, the occurence of a periocidity in both records of the geochemical and eruptive fluctuations through time strongly excludes that they are linked to sedimentary processes.

Although several hypotheses may be envisaged, the periodicity of magma influx into shallow reservoirs of about $24 \mathrm{kyr}$, similar to that of the precession of Earth's orbit, suggests that changes in glacio-eustatic pressure through time may be considered as a mechanism for controlling fluctuations in volcanic activity.

Acknowledgments. We thank E. Bard, S. Calvert, S. Carey, J.C. Duplessy, C. Jaupart, A. Mazaud, D. Paillard, M. Semet, and H. Sigurdsson for helpful discussions. We are greatly indebted to F. Albaréde, who provided very helpful comments, as did an anonymous reviewer. Cruises Etna-80 and Etna-82 of the French R/V Le Noroit and Le Surott were supported by IFREMER. Neutron activation analyses have been performed with facilities of the Pierre Süe laboratory in Saclay. The french Commissariat à l'Energie Atomique, the Centre National de la Recherche Scientifique and the programme Dyanmique et Bilan de la Terre, Instabilitiés, de l'INSU have contributed to financial support. This is C.F.R. contribution 1342.

\section{REFERENCES}

Albarède, F., Regime and trace-element evolution of open magmachambers, Nature,318, 356-358, 1985.

Allègre, C.J., and J.-F. Minster, Quantitative models of trace element behavior in magmatic processes, Earth Planet Sci. Lett., 38, 1-25, 1978.

Allègre, C.J., M. Treuil, J.-F. Minster, B. Minster, and F. Albarède, Systematic use of trace element in igneous process, Part I, Fractional crystallization processes in volcanic suites, Contrib. Mineral. Petrol., 60, 57-75, 1977.

Amienti, P., F. Barberi, H. Bizouard, R. Clochiati, F. Innocenti, N. Metrich, M. Rosi, and A. Sbrana, The Phlegrean Fields Magma evolution within a shallow chamber, J.Volcanol. Geotherm. Res., $17,289-311,1983$.

Baker, B.H., and A.R. McBimey, Liquid fractionation, Part III, Geochemistry of zoned magmas and the compositionnal effects of liquid fractionation, J. Volcanol. Geotherm. Res., 24, 55-81, 1985.

Barberi, F., F. Innocenti, L. Lirer, L. Munno, T. Pescatore, and R. Santacrocce, The Campanian Ignimbrite a major prehistoric eruption in the Neapolitan area (Italy), Bull. Volcanol., 41, 10-31, 1978.

Blake, S., and J.H. Fink, The dynamics of magma withdrawal from a density stratified dyke, Earth Planet. Sci. Lett., 85, 516-524, 1987.

Carrigan, C.R., and J.C. Eichelberger, Zoning of magmas by viscosity in volcanic conduits, Nature, 343, 248-251, 1990.

Chappell, J., On possible relationships between upper Quatemary glaciations, geomagnetism and volcanism, Eorth Planet. Sci. Lett., 26, 370-376, 1975 .

Civetta, L., Gallo, G. and G. Orsi, Sr- and Nd-isotope and traceelement constraints on the chemical evolution of the magmatic system of Ischia (Italy) in the last $55 \mathrm{ka}, J$. Volcanol. Geotherm. Res., 46, 213-230, 1991.

Crisci, G.M., A.M. De Francesco, R. Mazzuoli, G. Poli, and D. Stanzione, Geochemistry of recent volcanics of Ischia island, Italy Evidence for fractional crystallisation and magma mixing, $J$. Volcanol. Geotherm. Res., 17, 15-33, 1989.

Dzurisin, D., Influence of fortnightly earth tides at Kilauea volcano, Hawaï, Geophys. Res. Lett., 7, 925-928, 1980.

Fischer, R.V. and H.U. Schmincke, Pyroclastic Rocks, 472 pp. Springer-Verlag, New York, 1984.

Forcella, F., M. Gnaccolini, and L. Vezzoli, I deposil prroclastici del settore sud-orientale dell'isola d'Ischia (Italia), Riv. Ital. Paleont. Stratigr., 89, 135-170, 1983.

Hildreth, W., Gradients in silicic magma chambers Implications for lithospheric magmatism, J. Geophys. Res., 86, 10,153-10,192, 1981 .
Kennett, J.P., and R.C. Thunel, Global incrcase in Quatemary explosive volcanism, Science, 187, 497-503, 1975.

Kennett, J.P., A.R. McBimey, and R.C. Thunell, Episodes of Cenozorc volcanism in the Circum-Pacific Region, $J$ Volcanol. Geotherm. Res., 2, 145-163, 1977.

Lirer, R., G. Luongo, and R. Scandone, On the volcanological evolution of Campi Flegrei, EOS Trans AGU, 68, 226-234, 1987.

Mahood, G.A. and E.W. Hildreth, Pantelleria, a new interpretation, EOS Trans. AGU, 61, 1141, 1980.

Mathews, R.K., Tectonic implications of glacio-eustatic sea-level fluctuations, Earth Planet. Sci. Lett., 5, 459-462, 1969.

McBimey, A.R., Igneous Petrology, 504 pp, Freeman, Cooper, San Francisco, Calif.1984.

O'Hara, M.J., Geochemical evolution during fractional crystallisation of a periodically refilled magma chamber, Natwe , 266, 503-507, 1977.

O'hara, M.J., and R.E. Mathews, Geochemical evolution in an advancing, periodically replenished, periodically tapped, continuously fractionated magma chamber, J. Geol. Soc. London, 138, 237-277, 1981.

Pateme, M., Reconstruction de l'activité explosive des volcans de l'Italie du Sud par téphrochronologie marine, doctorat d'etat, 144 pp. Univ. Paris-Sud, 1985.

Pateme, M., F. Guichard, J. Labeyrie, P.-Y. Gillot, and J.-C. Duplessy, Tyrmenian Sea tephrachronology of the oxygen isotope record for the past 60,000 years, Mar. Geol., 72, 259-285, 1986.

Pateme, M., F.Guichard, and J.Labeyrie, Explosive activity of the south Italian volcanoes during the past 80,000 years as determined by marine tephrochronology, J. Volcanol. Geotherm. Res., 34, 153-172, 1988.

Pateme, M., J. Labeyrie, F. Guichard, A. Mazaud, and F. Maître, Fluctuations of the Campanian explosive volcanic activity (South Italy) during the past 190,000 years, as determined by marine tephroch ronology, Earth Planet. Sci. Lett., 98, 166-174, 1990.

Poli, S., S. Chiesa, P.-Y. Gillot, A. Gregnanin, and F. Guichard, Chemistry versus time in the volcanic complex of Ischia (Gulf of Naples, Italy) Evidence of successive magmatic cycles, Contrib. Mineral. Petrol., 95, 322-335, 1987.

Poli, S., S. Chiesa, P.-Y. Gillot, F. Guichard, and L. Vezzoli, Time dimension in the geochemical approach and hazards estimate of a volcanic area the isle of Ischia case (Italy), J. Volcanol. Geotherm Res., 36, 327-335, 1989.

Rampino, M.R., S. Self, and R.W. Fairbridge, Can rapid chmatic change cause volcanic eruptions?, Science, 206, 826-829, 1979.

Rosi, M., A. Sbrana, and C. Principe, The Phlegrean Fields Structural evolution, volcanic history and eruptive mechanism, J. Volcanol. Geotherm. Res., 17, 273-288, 1983.

Shackleton, N.J., Oxygen isotopes, ice and sea-level, Quat. Sci. Rev., 6, 183-190, 1987.

Sigurdsson, H., W. Comell, and S. Carey, Influence of magma withdrawal on compositional gradients during the AD 79 Vesuvius eruption, Nature, 345, 519-521, 1990.

Spera, F.J., C.M. Oldenburg, and D.A. Yuen, Magma zonation Effects of chemical buoyancy and diffusion, Geophys. Res. Lett., 16, 1387-1390, 1989.

Stothers, R.B., Volcanic eruptions and solar activity, J. Geophys. Res., 94, 17,371-17,381, 1989.

Treuil, M., and J. Varet, Critères volcanologiques, pétrologiques et géochimiques de la genèse et de la différenciation des magmas basaltiques, exemple de l'Afar, Bull. Soc. Géol. Fr., 7, 401-644, 1973.

Villemant, B., Trace element evolution in the Phlegrean Fields (Central Italy) Fractional crystallisation and selective enrichment, Contrib. Mineral. Petrol., 98, 169-183, 1988.

Walcott, R.I., Past sea levels, eustasy and deformation of the earth, Quat. Res., 2, 1-14, 1972.

E. Guichard and M. Paterne, Centre des Faibles Radioactivités, Domaine du CNRS, Avenue de la Terrasse, 91198 Gif sur Yvette Cedex, France.

(Received January 16, 1992;

revised October 23, 1992;

accepted November 5, 1992.) 